\title{
Piotr Stanisław Mazur, Metafizyka istnienia człowieka, Wydawnictwo Naukowe Akademii Ignatianum w Krakowie, Kraków 2018, ss. 174.
}

W swojej ostatniej monografii Piotr Stanisław Mazur podejmuje problematykę metafizyki klasycznej, starając się ją zaktualizować, rozszerzyć, uwiarygodnić, zwłaszcza w odniesieniu do antropologii filozoficznej, która miałaby być budowana na jej podstawach. To zainteresowanie metafizyką, jako wiedzą o całości rzeczywistości, badanej w aspekcie istniejącego bytu, ma kilka swoich przyczyn. Do najważniejszych z nich należy współczesna krytyka metafizyki klasycznej oraz coraz częściej podnoszone kwestie dotyczące tego, jak rozumieć realność istnienia. W swojej najnowszej monografii Mazur podejmuje próbę obrony tomistycznej metafizyki przez wskazanie na jej nowe, poznawcze możliwości związane z podstawami antropologii. Formułuje szereg pytań dotyczących istnienia człowieka, a konkretnie, na czym polega specyfika istnienia człowieka i co je charakteryzuje. Badania tego typu, według autora, powinny się oprzeć na podmiotowym doświadczeniu, na które składają się zarówno wewnętrzne przeżycia, jak i zewnętrzne manifestacje bytowe. Zagadnienia te Mazur wiąże z metafizyką istnienia człowieka, która pozostaje w polu ogólnej metafizyki (nauki o istniejącym bycie jako bycie), zachowując swoją względną autonomię, przynajmniej w obrębie specyfiki ludzkiej egzystencji oraz występowania zróżnicowanych, wielu form istnienia.

Swoje rozważania metafizyczne Piotr Mazur prowadzi w kręgu filozofii tomistycznej, zwłaszcza w nurcie tomizmu egzystencjalnego, którego podstawowe założenia podziela. Ogólnie przywołana tutaj metafizyka zakłada realność złożenia bytowego (istota i istnienie), 
przyjmując za obowiązujący pewien sposób rozumienia rzeczywistości. Zakładając, że istnienie jest pierwotne w stosunku do istoty, trzeba przyjąć, że byt istniejący jest bytem realnym, a to, co jest realne, jest również poznawalne jako istniejące. Wraz z daną koncepcją metafizyki, przyjmuje się za podstawę analiz pewną aparaturę pojęciową, reguły sensu, episteme oraz język. Rozbudowa metafizyki o problem istnienia człowieka konsekwentnie musi prowadzić do rozszerzenia pola episteme, co przynajmniej pośrednio wpływa na zmiany w pojmowaniu pozostałych wymienionych elementów. Autor, podejmując problematykę metafizyki istnienia człowieka, stoi przed dwoma trudnościami. Pierwsza $\mathrm{z}$ nich jest związana $\mathrm{z}$ zamiarem poszerzenia metafizycznego ujęcia istnienia o specyfikę istnienia człowieka. Druga trudność wyrasta $\mathrm{z}$ tego pierwotnego zamiaru i odnosi się do samej metafizyki - czy badania nad specyfiką istnienia człowieka wprowadzą zmiany w jej reguły sensu? Krótko mówiąc, chodzi nie tylko o to, czy podjęte przez Mazura badania metafizyczne prowadzą do rozważań nad samą metafizyką i wiarygodnością jej poznania. Inspirację i zachętę do zajęcia się tymi metafizycznymi analizami autor czerpie z filozofii współczesnej, z jej pytań o metafizykę, o realizm bytowy, o pierwotność istnienia. Refleksja metafizyczna i poprzedzające ją pytania nie dotyczą wprost uporządkowanej koncepcji bytu. Chodzi raczej o przekroczenie progu fragmentaryczności analiz i opisów na rzecz budowania wspólnych podstaw dla życia, różnych form egzystencji i istnienia bytowego. W niektórych środowiskach filozoficznych poszukuje się więc dzisiaj odpowiedzi metafizycznych, kierując się odrębnymi, poznawczymi intencjami i celami. Mazur próbuje powiązać je ze sobą, wskazując na różne treści i możliwe interpretacje doświadczenia istnienia człowieka. Tej idei integracji z zachowaniem różnorodności form istnienia i form bytowych podporządkowana jest struktura omawianej monografii o metafizyce istnienia człowieka.

Kompozycja pracy opiera się na holistycznym, pełnym opisie istnienia człowieka ujętego w związkach, jakie zachodzą między życiem, 
egzystencją, a osobowym, indywidualnym istnieniem. Te różne formy bytowania nakładają się na rozmaite struktury ontyczne i stanowią o ich treściowym bogactwie oraz znaczeniu. Poszczególne rozdziały monografii są poświęcone pięciu głównym tematom: począwszy od omówienia faktu istnienia, przez jego aspektowo i treściowo wyodrębnione formy, aż do problematyki transcendentaliów i dialogicznych form istnienia. Opis i analiza poszczególnych tematów przebiegają na trzech, powiązanych ze sobą poziomach. Na pierwszym poziomie analizie są poddawane przejawy (fenomeny) istnienia, wynikające $z$ określonej formy bytowej, następnie przechodzi się do ich interpretacji metafizycznej, co domaga się wprowadzenia odpowiedniej terminologii oraz narzędzi poznawczych. Trzeci poziom to formułowanie wniosków, które wiążą ze sobą - według przyjętego klucza interpretacyjnego - istnienie człowieka $\mathrm{z}$ istnieniem osobowym oraz z istnieniem bytu (jako jedności, całości i przygodności).

Poniżej, omawiając zawartość wspomnianych już rozdziałów, chciałabym zastanowić się nad kilkoma kwestiami: jaką funkcję pełni metafizyka, a konkretnie metafizyczny opis w filozoficznym ujęciu istnienia człowieka? Czy język klasycznej metafizyki jest adekwatny do bogactwa form i treści doświadczenia bycia człowiekiem? Pytania te są podyktowane przez treść doświadczenia istnienia; wydaje się, że skoro człowiek jest i staje się, to w tym ,jestem" kryje się zarówno zwrot podmiotu do siebie, jak i od siebie; jestem w sobie i jestem dla innych. Czy przeżycie tego, że jestem, jest tożsame z uchwyceniem swojego istnienia? Między stwierdzeniem własnej egzystencji (ja jestem) a doświadczeniem własnego istnienia musi pojawić się czas. Istnieję w czasie; byłam i jestem, chociaż nie wiem, jak długo będę. Czas konstytuuje świadomość własnego istnienia i innych, odsłania jego przygodność, skończoność. Jestem tu i teraz, a istnieję od - do jako określona, indywidualna osobowa forma bytu. Czy zatem metafizyka klasyczna proponuje inne rozumienie istnienia człowieka od potocznie przyjętego? $\mathrm{Na}$ czym będzie ono polegało i jak w jego ramach wyjaśnia się przejście z pozycji ,jestem” do „istnieję”? Należy 
dodać tytułem usprawiedliwienia, że autor, powołując się na wielu współczesnych fenomenologów i egzystencjalistów, wielokrotnie musiał spotkać się z tymi pytaniami. W swoich dociekaniach Mazur zakłada, że o ile istnienie jest faktem oczywistym, to sposób jego przeżywania i kontemplowania przesiąknięty jest tajemnicą. Pytając o istnienie, autor bada nie tylko jego przyczyny, ale też objawy, związki, zależności, które ujawniają jego różne, kontekstowe znaczenia. W tym celu omawia się istnienie jako fakt zewnętrzny i wewnętrzny, rozpisany na akty, przeżycia, stany egzystencjalne. „Jest więc nie tylko istnieniem podmiotowym (w sobie), ale też posiadającym pewne cechy kwalitatywne, kwantytatywne czy relacyjne" (s. 37).

Zgodnie z tymi deklaracjami, w pierwszej części autor pokazuje, jak istnienie związane jest $\mathrm{z}$ życiem i egzystencją, a zarazem $\mathrm{z}$ nich nie wynika. Dlatego autor wyjaśnia, że wszystkie doświadczenia istnienia, jakie skupione są wokół życia i egzystencji, stanowią pewien obszar partykularyzacji istnienia. Ujawniają się one w kręgu relacji i mają charakter komunikacyjny, a więc informują o istnieniu i jego konkretnym, relacyjnym położeniu. Tym samym przenoszą treści jednostkowych przeżyć, doświadczeń indywidualnych na poziom ogólny, bytowy. Konkluzja końcowa: istnienie przejawia się w różnych treściach i związkach, zachodzących między wewnętrznymi treściami przeżyć. Istnienie ujęte samo w sobie stanowi niepodzielną jedność, dzięki której jest ono dane i obecne w wieloraki sposób. Istnienie oznacza tutaj zarówno indywidualne bycie, jak i bycie realne. Te dwa momenty nie tyle są połączone doświadczeniem (konkretnie - treścią doświadczenia), ile założone jako pierwotne. W ich świetle można dopiero poznać różne podmiotowe relacje i przypadłości. Właśnie wyodrębnione jako relacje istniejącego bytu i jego przypadłości. Istnieć można na różne sposoby - czy istnienie realne ujawnia wszystkie formy egzystencji człowieka, czy życie ludzkie, w jego rozmaitych postaciach zamyka się w kręgu tego, co realne (faktyczne, rzeczywiste) i istniejące? Kolejne części pracy szczegółowo podnoszą 
najpierw kwestię biologicznych podstaw istnienia (część II) oraz jego kategorii egzystencjalnych (część III).

W drugim rozdziale autor stara się przede wszystkim uchwycić fenomen życia, rozważa nad tym, czym ono jest: o życiu decyduje dynamika procesów biologicznych, które charakteryzuje celowościowy perfekcjonizm. Chociaż doskonałość biologiczna została przez Mazura przypisana człowiekowi, to niewątpliwie można ją dostrzec w każdym żywym, rozwijającym się organizmie. Życie jako fenomen jest organizmem i zbiorem skoordynowanych procesów dynamicznych, i jako tak złożona całość może być rozpatrywane zarówno pod kątem całości, doskonałości, jak i celu. Autor zakłada, że sam fenomen życia nie tłumaczy specyfiki istnienia człowieka, ale jest jego aspektem, czyli jednym z realnych przejawów. Dotyczą one zarówno życia biologicznego, społecznego, jak i psychicznego, prowadzą do ukształtowania się wspólnotowych i indywidualnych cech, zależności i sposobów komunikowania. Życie to także początek i koniec bycia tu i teraz, który z perspektywy tomistycznej nie wiąże się z kresem istnienia człowieka. „Smierć jest kresem, ale nie unieważnia celu ludzkiego istnienia, bo czyni je trwale niezrealizowanym w porządku natury" (s. 63). Istnienie zatem w tym ujęciu (czy ściślej w tej tradycji) wykracza poza życie biologiczne, społeczne i psychiczne, a zarazem życie (trwanie i rozwój) nadaje osobowemu istnieniu konkretne atrybuty. Konkludując, istnienie jest pierwotne i podstawowe dla wszystkich zachodzących zmian, następujących po sobie etapów życia i wymiarów życia ludzkiego.

W trzeciej części swojej pracy Mazur zajmuje się problematyką egzystencjalną pod kątem jej kategorialnych związków z istnieniem. Autor wyjaśnia, że przez kategorie będzie rozumiał różne właściwości substancjalne, przypadłościowe i relacyjne. Kategorialne cechy istnienia opisują jego szczegółowe postacie, a więc właściwości konkretnego, zindywidualizowanego bycia, w odróżnieniu od całościowego ujęcia istnienia bytu opartego na własnościach tanscendentalnych. Związki między tymi dwoma własnościami istnienia 
- kategorialnymi i transcendentalnymi - wynikają z przyjęcia dwóch regulujących je zasad. Pierwsza $z$ nich wskazuje na to, że istnienie bytu (tj. substancji) jest jedno, a jego różne kategorialne aspekty są przypisane danemu podmiotowi jako jego szczegółowe przejawy istnienia. W odniesieniu do istoty przyjmuje się, że akt istnienia ją aktualizuje (urealnia) w porządku określonego bytu. A druga zasada zakłada, że pierwszeństwo istnienia wobec istoty prowadzi do tego, że ten akt urzeczywistnia istotę. „W rezultacie, stwierdza Mazur, kategorialne aspekty bytowania znajdują swoje przeżyciowe odzwierciedlenie w egzystencji podmiotu. Jednocześnie istnienie to wykracza poza wszystko, co dane jest w aktualnym poznaniu i przeżyciu" (s. 68).

Egzystencję człowieka rozpatruje się w tym rozdziale ze względu na jej aspekt substancjalny, kwalitatywny oraz kwantytatywny. Ogólnie, autor podąża drogą wyznaczoną przez neotomistów, wskazując na substancjalny wymiar istnienia człowieka uchwycony w jego sądzie egzystencjalnym ,ja istnieję". Podmiotowy sąd egzystencjalny stwierdza realność własnego istnienia, czyli konkretnego ,ja”. Sąd ten wyraża doświadczenie i przeżycie własnej egzystencji - ja działam, ja myślę, ja istnieję, ale nie jestem ani pełnią działania, ani myślenia, ani istnienia. Dopiero istniejąc, mogę działać, czuć i myśleć, z kolei moje istnienie nie wyczerpuje wszystkich realnych istnień. Podmiot, świadomy własnego istnienia, otwiera się na poznanie i wczucie w istnienie innych: ludzi, natury, a przede wszystkim Boga. Człowiek nie tylko żyje i rozwija się w świecie, ale także nawiązuje z nim różne rodzaje więzi i relacje. Dzięki czemu podmiot rozwija się, zmienia, nabiera określonych sprawności i kompetencji, które w sumie stanowią o jakościowych przypadłościach danej substancji.

Mazur podkreśla znaczenie, jakie dla jakościowego charakteru istnienia człowieka ma egzystencjalne przeżycie jego godności. Godność stanowi o etycznej, niezbywalnej jakości istnienia jednostki, ma swój pierwotny i odrębny status, wpływa zarówno na ludzką egzystencję, jak i na stosunek do innych oraz do siebie. Człowiek, 
jak utrzymują tomiści, posiada zdolność do doskonalenia moralnego i duchowego, do wszechstronnego rozwoju, do twórczej egzystencji. Jest bytem dramatycznym, skazanym na cierpienie, ból, klęski, samotność, porażki i śmierć. $Z$ tego też powodu jego egzystencji nie można sprowadzić do jednego schematu, przeciwnie, trzeba wziąć pod uwagę jej dynamizm, niepowtarzalność, zindywidualizowanie i tajemniczość jednostkowego losu.

Opis ten zostaje rozszerzony o wymiar ilościowy (kwantytatywny) obejmujący ludzkie ciało i zmiany, jakim ono podlega. Człowiek doświadcza siebie, swojego istnienia i innych w obrębie własnej cielesności. Sytuuje ona człowieka w świecie i zarazem określa go wobec wszystkiego, co jest inne, odrębne w stosunku do niego; umiejscawiając go w czasie i w przestrzeni. W ten sposób człowiek istnieje w historii, określonej czasem i przestrzenią, toteż opowiadając o sobie, buduje własną, narracyjną tożsamość, w której, dopowiedzmy, jego istnienie zostaje powiązane $\mathrm{z}$ własną historią życia, staje się miarą jego sensu i celem indywidualnej egzystencji. Stąd wypływa jej subiektywizm, a zarazem konkretne istnienie w historii jest powiązane z materialną rzeczywistością. Obydwie strony istnienia człowieka: subiektywna i obiektywna, uzupełniają się i tym samym stanowią podstawę do całościowego ujęcia jednostkowej egzystencji. Opis ten wymaga uzupełnienia o aspekt kategorialno-relacyjny. Jak wyjaśnia autor, przez relację należy rozumieć przyporządkowanie bytu do czegoś, co odnosi się do relacji wewnątrzbytowych, jak i zewnętrznych, obejmujących relacje międzybytowe. Relacje te są przypadłościami, ale uwarunkowanymi, i dlatego, nie mając wpływu na kondycję substancji, wyrażają specyfikę istnienia człowieka danego w jego sprawstwie. Mazur stara się precyzyjnie bliżej scharakteryzować te relacje, które kształtują i ujawniają różne sposoby manifestowania się osobowego istnienia. Należy do nich zaliczyć: zdolność podmiotu do samoposiadania siebie (a więc tego, który sam siebie posiada, a zarazem jest posiadany przez siebie), ułożenia siebie. Chodzi tutaj o wewnętrzny układ podporządkowania części względem całości; 
który dotyczy ciała, władz, wewnętrznych procesów dynamicznych oraz różnego rodzaju sprawności. Ostatecznie, układy te i relacje składają się na egzystencjalne przeżywanie istnienia na różnych poziomach działania oraz z próbą ich wewnętrznego, harmonijnego ułożenia. Tutaj też wymiar metafizyczny bytu jest współdany z jego opisem ontologicznym; to, co jest, i to, co się staje, przenika wzajemnie bytową sferę egzystencjalną.

Część czwarta pracy jest poświęcona istnieniu człowieka, ujętego od strony transcendentaliów. Autor konsekwentnie zmierza do opisu istnienia na dwóch płaszczyznach odnoszących się do indywidualnych przeżyć, doświadczeń życiowych i egzystencjalnych, by następnie przejść do ogólnobytowego wymiaru istnienia człowieka. Rozważenie tych kwestii wymaga bliższego wyjaśnienia, jak w wybranej koncepcji rozumie się metafizykę jako ogólną wiedzę o bycie, czym się charakteryzuje poznanie metafizyczne, jakimi dysponuje narzędziami poznawczymi oraz jakiego używa języka. Autor, co prawda, nie zajmuje się bezpośrednio analizą języka metafizyki, ale stara się niektóre pojęcia zdefiniować, rozszerzyć ich kontekst znaczeniowy. Mimo tych niezbędnych zabiegów wydaje się, że podjęte przez Mazura badania sprzyjają krytycznej analizie języka metafizyki klasycznej. I to nie tylko pod względem semantycznym, ale również szerszym, bo odnoszącym się do kultury humanistycznej. Metafizyka klasyczna jako wiedza zawiera w sobie pewną wizję rzeczywistości, która tkwi w języku, i dlatego powinna stać się sama w sobie przedmiotem badania, rekonstrukcji i ponownego przemyślenia. Autor omawianej pracy porusza się w pewnych bezpiecznych granicach orzekania o świecie i bycie ludzkim. Niemniej jednak podjęte przez niego kwestie wykraczają poza ustalone granice i prowadzą do dalszych pytań i kontrowersji. Na tym zresztą polegają korzyści płynące z lektur filozoficznych, które powinny inspirować, zachęcać do samodzielnego myślenia i stawiania pytań.

W badaniach Mazura nad istnieniem człowieka decydującą rolę odgrywa metoda separacji, którą autor rozwinął w swojej pierwszej 
monografii pt. Zarys podstaw filozofii cztowieka. Antropologiczne zastosowanie metody separacji (Kraków 2016). Metoda ta pozwala bowiem na łączenie ze sobą określonych treści bytowych z właściwym dla nich aktem istnienia.

W kolejnej części pracy podniesiona jest problematyka transcendentaliów w związku z badaniem istnienia człowieka. Ujęcie istnienia bytu z perspektywy transcendentaliów jest zasadniczo inne od antropologicznej charakterystyki istnienia, ponieważ odnosi się do koniecznych cech stanowiących o bycie samym w sobie, a nie do jego cech kategorialnych. Istnienie rozpatrywane pod rozmaitymi kątami stanowi podstawę jedności człowieka i jego przypadłościowego zróżnicowania. Toteż wymiar transcendentalny istnienia wskazuje na inne cechy bycia człowiekiem niż wymiar kategorialny. Przy tym, dzięki metodzie separacji, te dwie strony istnienia człowieka - jako bytu w sobie i bytu działającego, otwartego na innych, pozostają ze sobą w ścisłym związku na różnych poziomach wiedzy, poznania $\mathrm{i}$ interpretacji. Transcendentalne własności istnienia reprezentują takie własności bytowe jak: realność, przygodność, jedność, odrębność, prawda, dobro i piękno. Korzystając z licznych prac tomistów, Mazur każdą z tych własności omówił i poddał szczegółowej charakterystyce. Odwołajmy się do jednego z tych opisów, związanego z problematyką realności, którą autor podzielił na trzy płaszczyzny doświadczenia: obecność konkretnego bytu wśród innych bytów, doświadczenie istnienia ujawnione w sądzie egzystencjalnym oraz samo-doświadczenie podmiotowego ja. Trafna jest uwaga autora, że jeśli chce się rozumieć fenomen realnego (tj. faktycznego, autentycznego) istnienia w interpretacji tomistycznej, to trzeba go ująć zarówno od strony przedmiotowej (a więc i cielesnej), jak i podmiotowej (a więc i jaźni). „Tymczasem, jak metafizyka dąży do ujęcia całej, istniejącej rzeczywistości, tak antropologia winna uwzględnić każdy aspekt doświadczenia istnienia człowieka, aby dzięki temu dotrzeć do poznania tego, kim człowiek jest" (s. 100). Rozważając kolejno inne, wymienione już własności transcendentalne w związku z ludzkim 
istnieniem, Mazur nawiązuje nie tylko do lektur autorów tomistycznych, ale również do prac Ingardena i Stróżewskiego, Wojtyły $i$ innych myślicieli. Niewątpliwie, sięganie do analiz fenomenologicznych i egzystencjalnych wprowadza nowe wątki, formułuje też nowe problemy i wzbogaca materiał opisowy, co w wersji skumulowanej ma miejsce w rozdziale zatytułowanym Komunikatywno-dialogiczne aspekty istnienia.

Tak jak w poprzednich częściach tekstu, tak i w tym rozdziale autor zajmuje się określonym wymiarem istnienia pod wybranym kątem, czyli w tym przypadku istnieniem supratranscendentalnym, inaczej określanym jako ponadtranscendentalnym. Jego wyjątkowe znaczenie polega na tym, że wiąże ono ze sobą wymiar kategorialny istnienia $\mathrm{z}$ istnieniem kategorialnym. Mazur wyraźnie zaznacza, że ten rodzaj istnienia odnosi się tylko do człowieka, a więc istoty zdolnej do komunikacji w obszarze poznania, pożądania oraz twórczości. Człowiek istnieje wobec (innych, innego) oraz istnieje ku (innym, ku innemu) a także istnienie dla (siebie, innego, innych). Te trzy podstawowe relacje pozwalają na głębszą analizę trzech różnych sposobów odniesienia się własności transcendentalnych do kategorialnych. Zostały one rozpisane na trzy relacje, wyznaczone przez prawdę, dobro i piękno, i powiązane $z$ konkretnymi formami aktywności podmiotu. Podmiot ten jest zdolny nie tylko do aktów poznania w obrębie tego, co prawdziwe-fałszywe, dobre-złe i piękne-brzydkie, ale też do zajęcia określonego stosunku do nich, czyli akceptacji lub negacji. Komunikacja ludzka obejmuje świat dóbr i wartości, świat dialogiczno-osobowy oraz religijno-osobowy. Tym samym człowiek, działając, może wchodzić w relacje z wartościami, osobami i z Bogiem, w obrębie tych trzech sposobów istnienia: wobec, ku i dla. Pozwalają one na odkrycie bogactwa, stanowiącego o życiu człowieka i jego egzystencji, wraz z bogactwem różnych form dialogiczno-komunikacyjnych. Wśród nich autor wyodrębnia spotkania międzyosobowe, a w tym spotkanie z Bogiem. Jest ono tak 
niezwykłym i doniosłym wydarzeniem w życiu człowieka, że w jego kręgu dokonuje się znaczące przejście $\mathrm{z}$ istnienia ku w istnienie dla.

Warto podkreślić, że w ostatniej części pracy Mazur nie tylko rozszerzył opisy istnienia o komunikacyjno-dialogiczny aspekt, ale też, w dużym stopniu inspirując się filozofią dialogu i spotkania, odwołał sie do trzech jego form: istnienia wobec, ku i dla. Każda $\mathrm{z}$ tych form dialogiczno-komunikatywnych istnienia została opisana ze względu na właściwy sobie sposób odniesienia do prawdy, dobra i piękna, jak i do rzeczywistości podmiotu. Całość tego rozdziału stanowi bardzo ciekawy i być może nowatorski opis, a także analizę form komunikacyjnych istnienia człowieka. Ponieważ odnosi się on nie tylko do ludzkich możliwości poznawczych, ale i twórczych, z udziałem wolnej woli. Dobro, prawda i piękno, jako własności transcendentalne, jednocześnie stanowią nie tylko o tym, co jest przedmiotem ludzkiego działania, ale też wyjaśniają, dlaczego człowiek chce poznawać, myśleć, czuć i wybierać.

Wracając do bardziej ogólnych pytań i kwestii, jakie autor postawił przed sobą, warto odpowiedzieć na następujące: jakie są końcowe rezultaty przeprowadzonych badań nad metafizyką istnienia człowieka i jego specyfiką? Autor omawianej pracy w sześciu punktach stara się przedstawić najważniejsze twierdzenia, wynikające $\mathrm{z}$ jego rozważań. Można je sprowadzić do wymienionych tu twierdzeń: po pierwsze, wyróżniającą funkcją metafizyki tomistycznej w jej interpretacji egzystencjalnej jest „Związanie istnienia $z$ treściową stroną bytu oraz jego aktowy charakter stanowiący rację realności” (s. 154). Po drugie, poznanie metafizyczne, a zwłaszcza metoda separacji, pozwala na „relację doświadczenia podmiotowej (egzystencja) i przedmiotowej (życie, cielesność) strony istnienia”. W tych opisach można znaleźć też stwierdzenie bardzo ważne dla całego toku rozważań zawartych w omawianej monografii - poznanie metafizyczne jest ograniczone tylko do niektórych sposobów opisywania istnienia, ale, jak podkreśla autor, pozostają one tylko w gestii metafizyki. Trzecie istotne twierdzenie odnosi się do korelacji metafizyki do 
antropologii, rozpatrywanych pod kątem zarówno istnienia indywidualnego, jak i ogólnego, bytowego. „Proponowana interpretacja pierwszy aspekt uznaje za wyraz kategorialnego, a więc specyficznego dla człowieka sposobu istnienia, a drugi - za pełnię tego istnienia, wyrażającą się w jego ponadtranscendentalnym charakterze" (s. 154). Czwarte twierdzenie wypływa z założenia, że istnienie ludzkie jest przygodne otwarte na „dopełnienie na płaszczyźnie życia biologicznego, jak i osobowego, obejmujące dialogiczne relacje" (s. 155). Piąte twierdzenie, w nawiązaniu do poprzednich ustaleń, przypomina, że całe życie ludzkie związane jest $\mathrm{z}$ doświadczaniem istnienia $\mathrm{w}$ jego różnych aspektach, wymiarach i znaczeniach. To proces, który „nigdy nie może się zakończyć" (s. 156). Ostatnie, szóste twierdzenie, zwraca uwagę na specyfikę istnienia każdego człowieka, przypisaną jego własnej egzystencji. Doświadczenie bycia człowiekiem zawsze przebiega na miarę indywidualnego losu.

Na zakończenie chciałabym podzielić się pewnymi ważnymi uwagami, które dotyczą filozofii współczesnej, a zwłaszcza jej refleksji metafizycznej. Truizmem jest stwierdzenie, że można filozofować na różnych poziomach, z czego także wynika stosunek do metafizyki i jej poznawczych funkcji. Potrzeba metafizyki rodzi się wtedy, kiedy pojawiają się pytania o to, dlaczego istnieje raczej coś niż nic? Odpowiedź metafizyki tomistycznej koncentruje się na realności istnienia bytu, a więc odpowiada na pytania, co to znaczy istnieć (jakie muszą zostać spełnione warunki), jak manifestuje się istnienie i w jaki sposób wiąże ono ze sobą transcendentalne własności bytu z jego przypadłościowymi kategoriami. Dysponując takim materiałem i inspirując się antropologicznymi kwestiami podniesionymi przez filozofię współczesną, autor konsekwentnie w swojej pracy pokazał, w jaki sposób za pomocą poznania metafizycznego można opisać specyfikę sposobu istnienia człowieka. Z pewnością została zaprezentowana ciekawa i wszechstronna rekonstrukcja metafizyki neotomistycznej w obrębie badań nad specyfiką ludzkiego istnienia. Pozostają jednak otwarte pytania o to, czy istnienie to stawia 
człowieka przed otwartym wyborem jego więzi ze światem, czy te $\dot{z}$ człowiek istniejąc, konstytuuje swój stosunek do otoczenia, jako podmiot stający się i zmieniający się czasie. Na co wskazywałyby trzy momenty, a mianowicie: ujmujemy swoje istnienie w doświadczeniu, w życiu i w działaniu. Odkrycie własnego istnienia jest zawsze związane $z$ manifestacją siebie, swojego bycia, bycia naznaczonego pozytywnymi lub negatywnymi wartościami. A skoro człowiek poznaje, że istnieje, to znaczy, że nadaje mu określone znaczenie, wartość (dobrze, że jestem lub nienawidzę swojego życia, nie chcę tak dalej żyć). Akceptacja lub negacja własnego istnienia wynika wprost $\mathrm{z}$ oceny życia, jakie komuś przypadło w udziale. $\mathrm{Z}$ tym związane jest także doświadczenie czasu, w którym prezentuje się nam nasze własne życie, w różnych jego barwach aksjologicznych. Każde podmiotowe doświadczenie istnienia wyrażone w zdaniu „Ja istnieje” ma charakter aksjologiczny. Nie ma bowiem neutralnego aksjologicznego doświadczenia istnienia, i dotyczy to zarówno istnienia danego na zewnątrz, jak i wewnątrz. Właśnie tak potocznie każdy człowiek doświadcza swojego istnienia. Nawet jeśli wprost nie zdobywa się nigdy na formułowanie takich sądów egzystencjalnych podmiotowych, o których pisze autor recenzowanej pracy. Bycie nie tylko redukuje się do indywidualnego sposobu istnienia, ale jest zawsze dane wraz $\mathrm{z}$ oceną, $\mathrm{z}$ tym, jak konkretny podmiot interpretuje swoje życie, a więc i swoje istnienie. Zawsze bowiem znajdujemy się w matni określonego horyzontu aksjologicznego, jak trafnie pisał A. Węgrzecki. Autor interesującej nas monografii pośrednio nawiązuje do tych egzystencjalnych i dialogicznych obszarów istnienia. Jednak wydaje się, że właśnie o egzystencji i życiu ludzkim nie można nic ważnego powiedzieć, jeśli tych wszystkich aspektów się ze sobą nie połączy w pewną hermeneutyczną całość, ponieważ to dialogiczno-komunikatywne relacje stanowią ugruntowanie ludzkiego życia w odniesieniu do indywidualnej egzystencji. Taki kierunek rozważań niewątpliwie jest otwarty na przyjęcie hermeneutycznej (a nie metafizycznej i systemowej) perspektywy badań. Jeśli nawet jest to 
wybór drogi obciążony w dużym stopniu ryzykiem, to trzeba wziąć pod uwagę fakt, że autor, co prawda bardzo ostrożnie, ale już na nią wstąpił.

Z pewnością omawiana monografia Piotra Mazura, podobnie jak jego poprzednia praca, należy do najciekawszych, współczesnych studiów z zakresu metafizyki neotomistycznej. Co więcej, autor nie poprzestaje na - znanych $\mathrm{z}$ prac tomistów - opisach i analizach istnienia. Wprowadza nowe tematy, zadaje nowe pytania i stara się skonfrontować pole badawcze metafizyki ze współczesną filozofią. Czytając prace Piotra Mazura, można nie tylko zdobyć solidną dawkę wiedzy o metafizyce tomistycznej i jej możliwych powiązaniach $\mathrm{z}$ antropologią, ale też samodzielnie formułować kolejne pytania i próbować z pozycji metafizyki rzetelnie je rozważyć. Profesor Barbara Skarga twierdziła, że o filozofię bać się nie musimy, teksty Mazura dopowiadają, że nie filozofując, tj. nie uprawiając metafizyki, powinniśmy bać się o siebie, o swoją wiedzę.

EWA PODREZ

e.podrez@uksw.edu.pl

Uniwersytet Kardynała Stefana Wyszyńskiego w Warszawie, Instytut Filozofii

Wóycickiego 1/3, 01-938 Warszawa

ORCID: 0000-0001-5805-0869

DOI: $10.21697 /$ spch.2020.56.1.32 